Mira Rakić1, Beba Rakić1*, Ljiljana Stanojević

${ }^{1}$ Megatrend University, Graduate School of Business Studies, Serbia ${ }^{2}$ University Business Academy, Faculty of Applied Management, Economics and Finance, Serbia

\title{
Consumer Ethnocentrism - Marketing Challenge for Companies: The Case of Serbia
}

DOI: 10.7595/management.fon.2018.0019

\begin{abstract}
Research Question: This paper examines consumer ethnocentrism (CE) as marketing challenge for companies. Motivation: The purpose of the paper is to examine the antecedents and consequences of CE, who highethnocentric consumers are and whether CE can be used in marketing. Data: Results are derived from primary data collected from a consumer sample in Serbia during 2016 in retail stores of different retail chains in Belgrade. The sample included 200 examinees between 16 and 74 years of age. Tools: CE is measured by CETSCALE (consumer ethnocentric tendencies scale, 17 statements) developed by Shimp and Sharma (1987). Findings: The results indicate that $\mathrm{CE}$ can best be explained by a combination of national culture, the characteristics of consumers, product categories, the perceived value of companies and the integrated marketing communications of companies and countries. Furthermore, the results show that significant differences in CE exist between different groups of consumers and product categories. The theoretical contribution and the managerial impacts based on the findings are provided. The conceptual frameworks (Figure 1 and Figure 2) represent the theoretical contribution. The frameworks can be used by marketers for their effective target marketing (market segmentation, market targeting and market positioning). This study underlines different practical implications of a high level of CE for domestic and foreign companies in the Serbian market. Domestic companies have the opportunity to encourage $\mathrm{CE}$. This study provides marketers with useful marketing strategies and tactics for domestic and foreign companies with respect to $C E$. The high level of $C E$ is a marketing opportunity for domestic companies. Foreign companies face a bigger challenge with certain product categories which are directed towards certain groups - high-ethnocentric consumers. Particular challenges for foreign companies are promotional campaigns of domestic companies and governments in countries that are directed towards domestic products purchasing. Contribution: This study suggests the marketing strategies and tactics for the encouragement of CE for domestic companies. On the other hand, a high level of CE is a marketing threat to foreign companies. This study suggests the marketing strategies and tactics for decreasing the influence of CE for foreign companies. The results of this study can be used both for further research and in practice.
\end{abstract}

Keywords: consumers, consumer ethnocentrism (CE), marketing challenge, Serbia

JEL classification: M31, M38, M20

\section{Introduction}

Consumer ethnocentrism (CE) is an important issue for marketers (Balabanis \& Siamagka, 2017; Ding, 2017; Fernandez-Ferrin et al., 2015; Josiassen, Assaf \& Karpen, 2011; Li \& He, 2013; Raskovic et al., 2016; Seitz \& Roosen, 2015; Shankarmahesh, 2006; Shimp \& Sharma, 1987; Upadhyay \& Singh, 2006; Zeugner-Roth, Zabkar \& Diamantopoulos, 2015). The CE influences the attitudes and consumer behaviour toward domestic products and brands as better compared to foreign, and purchasing of domestic products and brands. By purchasing products/services of certain companies, consumers directly influence the survival of companies. CE can influence the consumers' preferences and the decisions to purchase domestic products. "Once consumer animosity and ethnocentrism levels have been measured, managers can then make decisions about whether to promote their country-of-origin ( $\mathrm{COO}$ ) or, alternatively, to create more powerful local con- 
nections for their products. Thus, the consideration of ethnocentrism can be part of a firm's international strategies" (Fernandez-Ferrin et al., 2015). The main objective of the paper is to examine the antecedents and consequences of CE, who high-ethnocentric consumers are, the effect of ethnocentrism on consumers' buying behaviour in different product categories and how ethnocentrism can be used in marketing. The remainder of the paper is organized as follows. In Section 2, theoretical foundations are presented and hypotheses are developed. Section 3 describes the method of research. Section 4 is devoted to the results of the research of CE in Serbia. The conclusion is presented in Section 5.

\section{Theoretical Foundations of Consumer Ethnocentrism and Development of Hypothesis}

Sumner (1906) was the first to define ethnocentrism in 1906 as: “... the view of things in which one's own group is the centre of everything, and all others are scaled and rated with reference to it... Each group nourishes its own pride and vanity, boasts itself superior, exalts its own divinities and looks with contempt on outsiders" (p. 13). Shimp and Sharma (1987, p. 280) have introduced the term "consumer ethnocentrism", which they use to represent the beliefs held by consumers about the appropriateness, indeed morality, of purchasing foreign made products. CE is a uniquely economic form of ethnocentrism, it describes consumer behaviour and it has marketing implications (Sharma et al., 1995). "The phenomenon of consumer preference for domestic products, or prejudice against imports, has been termed economic nationalism, cultural bias against imports, or consumer ethnocentrism" (Sharma et al., 1995, p. 26). From the perspective of ethnocentric consumers, people should always buy domestic-made products instead of imports; only those products that are unavailable in domestic market should be imported. Buying domestic-made products enables domestic business and employment. Purchasing imported products is wrong because it hurts the domestic economy, causes loss of jobs, and is plainly unpatriotic. On the other hand, from the perspective of non-ethnocentric consumers, products should not be rated and decisions about buying should not be made on the basis of the country of origin - where they are produced (Shimp \& Sharma, 1987). "In functional terms, consumer ethnocentrism gives the individual a sense of identity, feeling of belongingness, and, most important for our purposes, an understanding of what purchase behaviour is acceptable or unacceptable to the in-group" (Shimp and Sharma, 1987, p. 280). Highly ethnocentric consumers generally favour domestic products over foreign alternatives (Supphellen \& Grrnhaug, 2003, p. 212). The consequences of consumer ethnocentricity include overestimation of the quality and value of domestic products or underestimation of the virtues of imports, a moral obligation to buy domestic products, and preference for domestic products and/or services (Kaynak \& Kara, 2001, p. 462).

Researchers have examined the impacts of numerous factors on CE. In the literature the following influences are analysed: national culture (He \& Wang, 2015; Kaynak \& Kara, 2001); country of origin (COO) (Bernabeu, Prieto \& Diaz, 2013; De Nisco et al., 2016; Evanschitzky et al., 2008; Fernandez-Ferrin \& BandeVilela, 2013; Huddleston, Good \& Stoel, 2001; Javalgi et al., 2005; Jin et al., 2015; Liu et al., 2006; Liu \& Chang, 2011; Moon \& Jain, 2002; Wang \& Chen, 2004; Watson \& Wright, 2000); demographic factors such as age, gender, income, education etc. (Evanschitzky et al., 2008; Fernandez-Ferrin et al., 2015; Haque \& Maheshwari, 2015; Neese \& Hult, 1996; Raskovic et al., 2016; Seitz \& Roosen, 2015; Sharma et al., 1995; Smaiziene \& Vaitkiene, 2014; Upadhyay \& Singh, 2006); product categories (Garmatjuk \& Parts, 2015; Sharma et al., 1995); perceived product quality (Huddleston, Good \& Stoel, 2001; Liu et al., 2006; Smaiziene \& Vaitkiene, 2014; Wang \& Chen, 2004), etc.

\subsection{National Culture and Characteristics of Consumers}

When researching CE in a certain country, the starting point is national culture. Members of a high-context culture (i.e., Japan, China) are more ethnocentric than members of a low-context culture (i.e., USA and Western European countries), though there might be some similarities between the two cultural groupings in terms of subgroups (i.e., teen market, upscale consumer market) (Kaynak \& Kara, 2001, p. 461).

The relationship between country similarity and the country-of-origin (COO) effect has been researched widely (Balabanis \& Siamagka, 2017; Bernabeu, Prieto \& Diaz, 2013; De Nisco et al., 2016; Ding, 2017; Evanschitzky et al., 2008; Javalgi et al., 2005; Jin et al., 2015; Liu et al., 2006; Liu \& Chang, 2011; Moon \& Jain, 2002; Wang \& Chen, 2004; Watson \& Wright, 2000). The country-of-origin effect, also known as the "made in" concept, has been broadly defined as a positive or negative influence that a product's country of manufacture may have on consumers' decision-making processes or subsequent behaviour (Watson \& Wright, 2000, p. 1151). Watson and Wright (2000) investigated the relationship between consumer ethnocentrism and consumer attitudes toward foreign-manufactured products in product categories in which domestic alternatives are not available. Their results suggest that cultural similarity is an important consideration for highly ethnocentric con- 
sumers in the evaluation of foreign products. Individuals with high levels of CE have more favourable attitudes toward products from culturally similar countries in comparison to products from culturally dissimilar countries. In such situations, the use of country of origin information may be strategically advantageous for foreign companies from countries classified as culturally similar. In contrast, foreign companies from culturally dissimilar countries should reduce their emphasis on the country of origin of the product. It is better to promote other attributes and benefits of the product. In addition, strategic benefits may also be gained by establishing alliances with domestic distributors and other companies (Watson \& Wright, 2000).

Important demographic characteristics of the customers that influence CE are: age, education, income, gender etc.

Age influences CE (Ding, 2017; Fernandez-Ferrin et al., 2015; Haque \& Maheshwari, 2015; Javalgi et al., 2005; Josiassen, Assaf \& Karpen, 2011; Seitz \& Roosen, 2015; Sharma et al., 1995; Upadhyay \& Singh, 2006). Generally speaking, older people are more conservative, more patriotic and ethnocentric. Attitudes toward domestic products become more favourable with increasing age. On the other hand, the younger generation may be more cosmopolitan (Sharma et al., 1995). To explore this issue, the following hypothesis is tested: $\mathrm{H} 1$ : Older consumers are more ethnocentric consumers than younger consumers.

Education is another demographic variable (Ding, 2017; Fernandez-Ferrin et al., 2015; Javalgi et al., 2005; Neese \& Hult, 1996; Seitz \& Roosen, 2015; Upadhyay \& Singh, 2006). Less educated consumers are generally more negative towards imported products, and those with higher education show more positive attitudes towards the quality of foreign-made products (Neese \& Hult, 1996). Therefore, it is hypothesized: $\mathrm{H} 2$ : Less educated consumers are more ethnocentric consumers than more educated consumers.

Income also influences CE (Javalgi et al., 2005; Josiassen et al., 2011; Sharma et al., 1995). The higher the income, the higher are the possibilities of travelling abroad, purchasing other countries' products which can develop more cosmopolitan views and greater openness to foreign products (Sharma et al., 1995). Therefore, we propose:

H3: Lower-income consumers are more ethnocentric consumers than higher-income consumers.

\subsection{Product Categories and Perceived Product Value}

CE is not the same in all product categories (Balabanis \& Siamagka, 2017; Evanschitzky et al., 2008; Garmatjuk \& Parts, 2015; Sharma et al., 1995). Thus:

$\mathrm{H} 4$ : $\mathrm{CE}$ is higher in the category of foodstuff than in some other product categories.

Consumers' intention to purchase domestic/foreign products depends on perceived product quality (Balabanis \& Siamagka, 2017; Ding, 2017; Evanschitzky et al., 2008; Huddleston, Good \& Stoel, 2001; Liu et al., 2006; Sharma \& Wu, 2015; Smaiziene \& Vaitkiene, 2014; Wang \& Chen, 2004). Perceived product quality is influenced by numerous factors such as appearance, colour and design, durability, fashion, functionality, prestige, reliability, technical advancement, value for money, and workmanship. The impact of ethnocentrism on consumer willingness to buy domestic products is lower when consumers perceive these products as lower quality products (Wang \& Chen, 2004). "Foreign products have an advantage over domestic products, in terms of the famous brand name and fashionable image" (Ding, 2017, p. 552). In the process of making decisions on buying, a consumer analyses numerous factors, among them: quality, price, total experience etc., which impact the perception of benefits (on the basis of buying and using products). A consumer determines perceived product value on the basis of perceived benefits. Based on these discussions, the following hypothesis is derived: H5: CE is higher when the perceived product value is higher than when it is lower.

\subsection{IMC of Companies and Countries}

Integrated marketing communications (IMC) enables an exchange of messages with the target groups of the public (Filipovic \& Kostic-Stankovic , 2011; Kitic et al., 2015; Kostic-Stankovic, 2011; Kostic-Stankovic \& Nedeljkovic, 2012; Rakic \& Rakic, 2017a, 2017b). Patriotic advertisements remind consumers of their duty to choose domestic-made goods over imports (Sharma et al., 1995). Companies and governments of countries can conduct promotional campaigns directed towards domestic products buying. For example, the Government of the Republic of Serbia conducted a campaign called "Let's buy domestic". Furthermore, the domestic retail chain "DIS" (in Serbia) in 2012 started a campaign "Buy domestic in a domestic store". For their advertisements they engaged the world's number one tennis player - a proud Serb Novak Djokovic who invites the consumers to buy domestic products in a domestic store. Consequently, it can be hypothesized that: 
H6: CE is positively related to the IMC of domestic companies and the governments of countries.

$\mathrm{H} 7$ : CE is positively related to the education of consumers about the importance of buying domestic products and brands.

\subsection{Purchasing Decision}

Besides attitudes, consumer behaviour is also important in the process of making decisions about purchasing products/services. According to Kaynak and Kara (2001), input (country-of-origin, product class knowledge, consumer characteristics, country characteristics and other variables) moderated by CE affect the output which can be observed as attitudes (product brand perceptions, perceptions of price, purchase intentions) and behaviour (choice of brand, purchase of brand). Thus, to evaluate the influence of attitudes on specific consumer behaviour, i.e., on purchase decision making, we propose the following hypothesis: H8: Purchasing decision of domestic products and brands is positively related to highly ethnocentric consumers.

\section{Methodology}

In addition to secondary data, the gathering of primary data through a survey was also carried out. The survey was conducted on the Serbian market in 2016. The biggest city/market in Serbia - Belgrade - was selected as the location for data collection. Convenience sample included 200 individuals between 16 and 74 years of age. The questionnaires were randomly distributed to buyers in front of the retail stores of different retail chains in Belgrade in 2016. A total of 200 questionnaires with complete data were collected.

Respondents, according to their age, were divided into the following groups: $16-34$ (20\%), $35-54$ (32\%), 55$74(48 \%)$. According to gender, the sample consisted of $51 \%$ of women and $49 \%$ of men. According to educational level, the respondents were grouped using EUROSTAT classification: 0-2 basic, lower secondary education (preschool education; primary education or the first phase of the primary education - first to fifth grade; lower high education - 6th to 9th grade); 3-4 higher secondary education (high school; - 1st to 4th grade; post secondary but not tertiary education - first degree studies); 5-6 tertiary education (higher education, Master studies and PhD studies). In the sample, $25 \%$ of the respondents had lower than secondary education, $50 \%$ had secondary education and $25 \%$ had tertiary education. According to the employment status, the respondents were divided into following groups: employed $(30 \%)$, unemployed $(25 \%)$, students $(5 \%)$, other but unemployed $(40 \%)$. According to income of the households where they live, the respondents were divided into following groups: up to 300 euro $(65 \%)$, more that 300 euro $(35 \%)$.

A questionnaire consisted of three parts. The first part of the questionnaire included questions about CE. Shimp \& Sharma (1987) developed a 17-item scale known as the CETSCALE (Consumer Ethnocentric Tendencies SCALE) to measure CET. The starting point for the research in this paper represents the CETSCALE which has been adjusted to research on the Serbian market as a domestic market. A 7-point Likert-type scale has been used (strongly agree $=7$, strongly disagree $=1$ ). The range of scores is from 17 to 119 (due to the use of the sevenpoint scale). In the second part the questions were being asked in order to research the interdependence of CE (on the one hand) and product categories, promotional campaigns and the education of consumers about the importance of purchasing domestic products (on the other hand). The third part of the questionnaire involves questions that are related to demographic consumer characteristics (e.g., age, gender, education, income).

In order to research the differences in CE by product categories, the following question was put:

RQ1. In which product categories domestic products are better?

Provided answers were: food, beverages, health \& health care, electronic products, household products, personal care \& beauty, cleaning products, clothing and footwear products and automobiles.

In order to research the impact of the perceived product value of domestic companies, the following questions were put:

RQ2.1. Does the perceived high product value of domestic companies influence the positive attitude about the importance of domestic products purchasing?

RQ2.2. Does the perceived low product value of domestic companies influence the negative attitude about the importance of domestic products purchasing?

Next, in order to research the relationship between promotional campaigns (of domestic companies and/or countries) and CE, the following question was asked:

RQ3. Do promotional campaigns (of domestic companies and/or countries) affect the attitude about the importance of purchasing domestic products? 
Also, in order to research the relationship between the consumers' education about the importance of domestic products purchasing and $\mathrm{CE}$, the respondents were asked the following question:

RQ4. Do you know what CE is?

The respondents who did not know what CE was were briefly informed about the importance of domestic products purchasing. All respondents were asked the following question:

RQ5. Would the consumers' education affect the consumers' decisions about larger purchase of domestic products compared to foreign products?

Finally, the question related to purchasing behaviour (and not only purchase attitudes) was asked:

RQ6. (to ethnocentric consumers): Do positive attitudes about the domestic products purchase importance affect the decision about buying and buying itself of domestic products/services and brands?

The collected data were analyzed using the Statistical Package for Social Science (SPSS). First, normal distribution was approved by Kolmogorov-Smirnov test. Then, 10 items measured respondents' perception of domestic products. For each subgroup the Cronbach's alpha were checked. The results are presented in Table 1 for education subgroups, Table 2 for emloyment subgroups and Table 3 for income subgroups. Then, the one-way Analysis of Variance (ANOVA) was used to test the first research question and any mean difference in consumers' ethnocentrism with regard to age group, education and income. The remaining research question, relationships among perceived product value and consumers attitude, the relationship between promotional campaigns and product value, consumers' education and consumers' decisions about purchase of domestic product, was tested by Pearson correlation analysis.

Table 1: Cronbach's Alpha for education subgroups

\begin{tabular}{ll}
\hline Education & Cronbach's Alpha \\
\hline Lower secondary education & 0.869 \\
High secondary education & 0.866 \\
Tertiary education & 0.854 \\
\hline
\end{tabular}

Table 2: Cronbach's Alpha for employment status subgroups

\begin{tabular}{ll}
\hline Employment status & Cronbach's Alpha \\
\hline Employed & 0.883 \\
Unemployed & 0.826 \\
Students & 0.733 \\
Other but unemployed & 0.870 \\
\hline \multicolumn{1}{c}{ Table 3: Cronbach's Alpha for income subgroups } \\
\hline Income & Cronbach's Alpha \\
\hline Up to 300 euro & 0.851 \\
$>300$ euro & 0.879 \\
\hline
\end{tabular}

As can be noted from Table 1, Table 2 and Table 3, reliability and internal consistency of scale were proven.

\section{Results and Discussion}

This study confirms the findings obtained in an earlier study conducted in Serbia (Gasevic, Tomasevic \& Vranjes, 2017; Kragulj, Parezanin \& Miladinovic, 2017; Marinkovic, Stanisic \& Kostic, 2011). Marinkovic, Stanisic \& Kostic (2011) show that the level of CE is higher in rural than in urban population; it is higher in older than in younger people; it is higher in men than in women. A relatively high and important correlation between the level of CE was observed, on the one hand, and the buying preferences and buying behaviour, on the other hand. Fernandez-Ferrin et al. (2015) investigated CE and consumer animosity in Belgrade (Serbia) shortly after the US-led NATO operations of 1999. The results obtained confirm that CE impacts one's product judgments and willingness to buy with respect to all foreign products, whereas animosity impacts one's willingness to buy, but does not have an impact on one's product judgments. Also, Fernandez-Ferrin et al. (2015) identified the correlates of the standard segmentation variables that affect the probability of a consumer holding animosity or possessing ethnocentric beliefs. The elderly people with the low levels of education who are very patriotic and not quite concerned about the national economy are more likely to demonstrate the high levels of ethnocentrism. Ethnocentric consumers will be more critical of the quality of foreign products and will show less willingness to buy such products. 


\subsection{The Main Results of the Research}

To answer research question 1, one-way ANOVA was used to determine whether there was any significant mean difference in consumers ethnocentrism as regards age, education and income.

Tukey's post hoc was used to discover which age group, income and educational group showed the significant difference.

Table 4 represents the Tukey's post hoc test for age group. The results revealed that respondents who were between 55-74 years old had the highest mean score and showed much higher level of economic patriotism relative to the youngest age groups (16-34 and 35-54) $(\mathrm{H} 1)$. It follows that $\mathrm{H} 1$ is proven, that older consumers are more ethnocentric consumers than younger consumers.

Table 4: One-way ANOVA and post hoc comparisons for age groups

\begin{tabular}{|c|c|c|c|c|c|c|c|c|c|c|}
\hline & \multicolumn{6}{|c|}{ Age groups } & \multicolumn{4}{|c|}{ post hoc comparisons } \\
\hline & \multicolumn{2}{|c|}{$16-34(1)$} & \multicolumn{2}{|c|}{$35-54(2)$} & \multicolumn{2}{|c|}{$55-74(3)$} & \multirow[b]{2}{*}{ p } & 1 vs. 2 & \multirow{2}{*}{$\frac{1 \text { vs. } 3}{p}$} & \multirow{2}{*}{$\frac{2 \text { vs. } 3}{p}$} \\
\hline & M & SD & M & SD & M & SD & & p & & \\
\hline Food & 6.3 & 0.823 & 6.38 & 0.495 & 6.5 & 0.516 & 0.000 & 0.651 & 0.001 & 0.000 \\
\hline $\begin{array}{l}\text { Beverages } \\
\text { Health \& health }\end{array}$ & 5.3 & 1.059 & 5.13 & 1.727 & 5.38 & 1.061 & 0.000 & 0.752 & 0.000 & 0.002 \\
\hline $\begin{array}{l}\text { care } \\
\text { Electronic }\end{array}$ & 4.8 & 0.632 & 4.75 & 1.389 & 5 & 0.756 & 0.001 & 0.723 & 0.021 & 0.000 \\
\hline $\begin{array}{l}\text { products } \\
\text { Household }\end{array}$ & 2.63 & 0.916 & 3 & 1.282 & 3.25 & 1.054 & 0.002 & 0.092 & 0.001 & 0.000 \\
\hline products & 3 & 0.949 & 3.3 & 1.195 & 3.5 & 1.195 & 0.001 & 0.341 & 0.023 & 0.001 \\
\hline $\begin{array}{l}\text { Personal care \& } \\
\text { beauty }\end{array}$ & 3.63 & 1.408 & 3.88 & 1.246 & 3.9 & 1.101 & 0.001 & 0.342 & 0.001 & 0.000 \\
\hline Cleaning products & 3.38 & 1.302 & 3.9 & 1.101 & 4 & 1.309 & 0.003 & 0.543 & 0.002 & 0.001 \\
\hline $\begin{array}{l}\text { Clothing and } \\
\text { footwear products }\end{array}$ & 3.13 & 1.356 & 3.38 & 1.302 & 4.5 & 1.269 & 0.002 & 0.423 & 0.001 & 0.003 \\
\hline Automobiles & 2 & 0.471 & 1.75 & 0.463 & 2 & 0 & 0.001 & 0.655 & 0.001 & 0.000 \\
\hline
\end{tabular}

Presented below are the results of Tukey's post hoc test that was conducted in order to assess which educational group showed the significant difference (Table 5). The stated data are in accordance with $\mathrm{H} 2$, according to which less educated consumers are more ethnocentric consumers than more educated consumers.

Table 5: One-way ANOVA and post hoc comparisons for Ceducation

\begin{tabular}{|c|c|c|c|c|c|c|c|c|c|c|}
\hline & \multicolumn{6}{|c|}{ Education groups } & \multirow[b]{3}{*}{$\mathbf{p}$} & \multicolumn{3}{|c|}{ post hoc comparisons } \\
\hline & \multicolumn{2}{|c|}{$\begin{array}{c}\text { Lower } \\
\text { secondary } \\
\text { education (1) }\end{array}$} & \multicolumn{2}{|c|}{$\begin{array}{c}\text { High } \\
\text { secondary } \\
\text { education } \\
(2) \\
\end{array}$} & \multicolumn{2}{|c|}{$\begin{array}{l}\text { Tertiary } \\
\text { education } \\
\text { (3) }\end{array}$} & & \multirow{2}{*}{$\frac{1 \text { vs. } 2}{p}$} & \multirow{2}{*}{$\frac{1 \text { vs. } 3}{p}$} & \multirow{2}{*}{$\frac{2 \text { vs. } 3}{p}$} \\
\hline & M & SD & M & SD & M & SD & & & & \\
\hline Food & 6.62 & 0.506 & 6.39 & 0.488 & 6.29 & 0.951 & 0.000 & 0.132 & 0.001 & 0.000 \\
\hline $\begin{array}{l}\text { Beverages } \\
\text { Health \& health }\end{array}$ & 5.43 & 1.134 & 5.42 & 1.311 & 4.86 & 1.345 & 0.001 & 0.324 & 0.000 & 0.001 \\
\hline $\begin{array}{l}\text { care } \\
\text { Electronic }\end{array}$ & 5 & 0.816 & 4.83 & 1.115 & 4.71 & 0.756 & 0.000 & 0.125 & 0.001 & 0.000 \\
\hline products & 3.93 & 1.044 & 3.51 & 1.215 & 2.71 & 1.113 & 0.000 & 0.432 & 0.001 & 0.001 \\
\hline $\begin{array}{l}\text { Household } \\
\text { products }\end{array}$ & 3.43 & 1.512 & 3.33 & 0.985 & 3 & 0.816 & 0.001 & 0.354 & 0.000 & 0.011 \\
\hline $\begin{array}{l}\text { Personal care \& } \\
\text { beauty } \\
\text { Cleaning }\end{array}$ & 3.86 & 1.069 & 3.83 & 1.115 & 3.71 & 1.604 & 0.002 & 0.234 & 0.001 & 0.001 \\
\hline $\begin{array}{l}\text { products } \\
\text { Clothing and } \\
\text { footwear }\end{array}$ & 3.86 & 1.069 & 3.75 & 1.138 & 3.71 & 1.604 & 0.000 & 0.123 & 0.002 & 0.001 \\
\hline products & 4.17 & 1.267 & 4.14 & 1.345 & 3.71 & 1.604 & 0.002 & 0.416 & 0.001 & 0.000 \\
\hline Automobiles & 2.89 & 0 & 2.67 & 0.488 & 1.71 & 0.426 & 0.001 & 0.115 & 0.000 & 0.000 \\
\hline
\end{tabular}


Table 6 represents the results of t-test that was used to discover whether there is a significant difference among different income group. The results revealed that the group of respondents with income up to 300 euro have a higher mean and that differences are significant $(p<0.05)$. So we can conclude that respondents with income up to 300 euros are more ethnocentric than consumers with higher income (>300 euro) $(\mathrm{H} 3)$. This is in accordance with $\mathrm{H} 3$ which states that lower-income consumers are more ethnocentric consumers than higher-income consumers.

Table 6: The results of Independent T-test

\begin{tabular}{|c|c|c|c|c|c|}
\hline & \multicolumn{2}{|c|}{ Income $<300$} & \multicolumn{2}{|c|}{ Income $>\mathbf{3 0 0}$} & \multirow[b]{2}{*}{$\mathrm{p}$} \\
\hline & $\mathrm{M}$ & SD & $\mathrm{M}$ & SD & \\
\hline Food & 6.56 & 0.527 & 6.29 & 0.488 & 0.004 \\
\hline Beverages & 6.33 & 0.577 & 5 & 1.732 & 0.002 \\
\hline Health \& health care & 5.67 & 0.577 & 4.71 & 1.254 & 0.000 \\
\hline Electronic products & 3.67 & 1.528 & 2.71 & 1.254 & 0.004 \\
\hline Household products & 4.33 & 0.577 & 3.14 & 1.215 & 0.012 \\
\hline Personal care \& beauty & 4.33 & 0.577 & 3.43 & 1.397 & 0.000 \\
\hline Cleaning products & 4.33 & 1.155 & 3.29 & 1.254 & 0.045 \\
\hline Clothing and footwear products & 4.33 & 1.155 & 3.43 & 1.397 & 0.002 \\
\hline Automobiles & 2 & 0 & 1.88 & 0.5 & 0.001 \\
\hline
\end{tabular}

The one-way ANOVA results also revealed that CE is higher in the category of foodstuff than in some other product categories (Table 4, 5 and $6-\mathrm{H} 4$ ). It follows that $\mathrm{H} 4$ has been proved according to which $\mathrm{CE}$ is higher in the categories of foodstuff than in other product categories.

In order to answer the remaining research questions Pearson correlation analysis was carried out. The results of Pearson correlations are presented in Table 7.

Table 7: Pearson correlations for pairs of CE

\begin{tabular}{|c|c|c|c|}
\hline Pairs & Coefficients & $\mathbf{N}$ & $p$ \\
\hline Perceived product value / consumers attitude ( $r 1)$ & 0.75 & 200 & 0.000 \\
\hline $\begin{array}{l}\text { Integrated marketing communications (IMC) / consumers ' } \\
\text { ethnocentrism (r2) }\end{array}$ & 0.83 & 200 & 0.000 \\
\hline Education of consumers / consumers 'ethnocentrism ( $\mathrm{r} 3$ ) & 0.71 & 200 & 0.000 \\
\hline $\begin{array}{l}\text { Consumers' attitudes about the domestic products purchase } \\
\text { importance/ decision about buying domestic products ( } \mathrm{r} 4)\end{array}$ & 0.80 & 200 & 0.000 \\
\hline
\end{tabular}

The perceived product value has a high and positive relationship with $C E(r 1=0.75, p=0.000)$. This result indicates that $\mathrm{CE}$ is in strong relationship with perceived product value (H5). It follows that $\mathrm{CE}$ is higher when the perceived product value of domestic companies is higher than when it is lower. This is in accordance with H5. Integrated marketing communications (IMC) of domestic companies and the governments of countriesis are also highly and positively correlated $(r 2=0.83, p=0.000)$ with $C E$. The high correlation shows that high IMC leads to positive CE (H6). Thus, it can be concluded that $\mathrm{CE}$ is positively related to the IMC of domestic companies and the governments of countries. This is in accordance with H6. Furthermore, education of consumers about the importance of buying domestic products and brands is highly and positively correlated $(r 3=0.71, p=0.000)$ with consumers 'ethnocentrism. The high correlation show that the more consumers ' education about importance of buying domestic products and brands leads to positive CE $(\mathrm{H} 7)$. It can be concluded that CE is positively related to the education of consumers about the importance of purchasing domestic products and brands. This is in accordance with H7. In addition, consumers ' attitudes about the domestic products purchase importance is strongly correlated $(r 4=0.80, p=0.000)$ with the decision about buying a domestic product. The findings imply that positive attitudes about the domestic products purchase importance help in making the decision about buying domestic products/services and brands (H8). It can be concluded that purchasing decision of domestic products and brands is positively related to the highly ethnocentric consumers. This is in accordance with $\mathrm{H} 8$. 


\subsection{Theoretical Implications}

This paper expands the prior research (Marinkovic, Stanisic \& Kostic, 2011) by exploring CE with the conceptual frameworks (Figure 1 and Figure 2). The first conceptual framework was developed in order to enable a better understanding of ethnocentric consumers' behavior (Figure 1). The second conceptual framework was developed as a guide for domestic and foreign marketers facing ethnocentric consumers' behaviour (Figure 2).

The previous sections have shown that the antecedents of the high level of CE are: national culture, characteristics of consumers, product categories, perceived value of products and integrated marketing communication (IMC) of companies and countries (see Figure 1). CE influences the attitudes toward domestic products and brands as better compared to foreign, and purchasing of domestic products and brands.

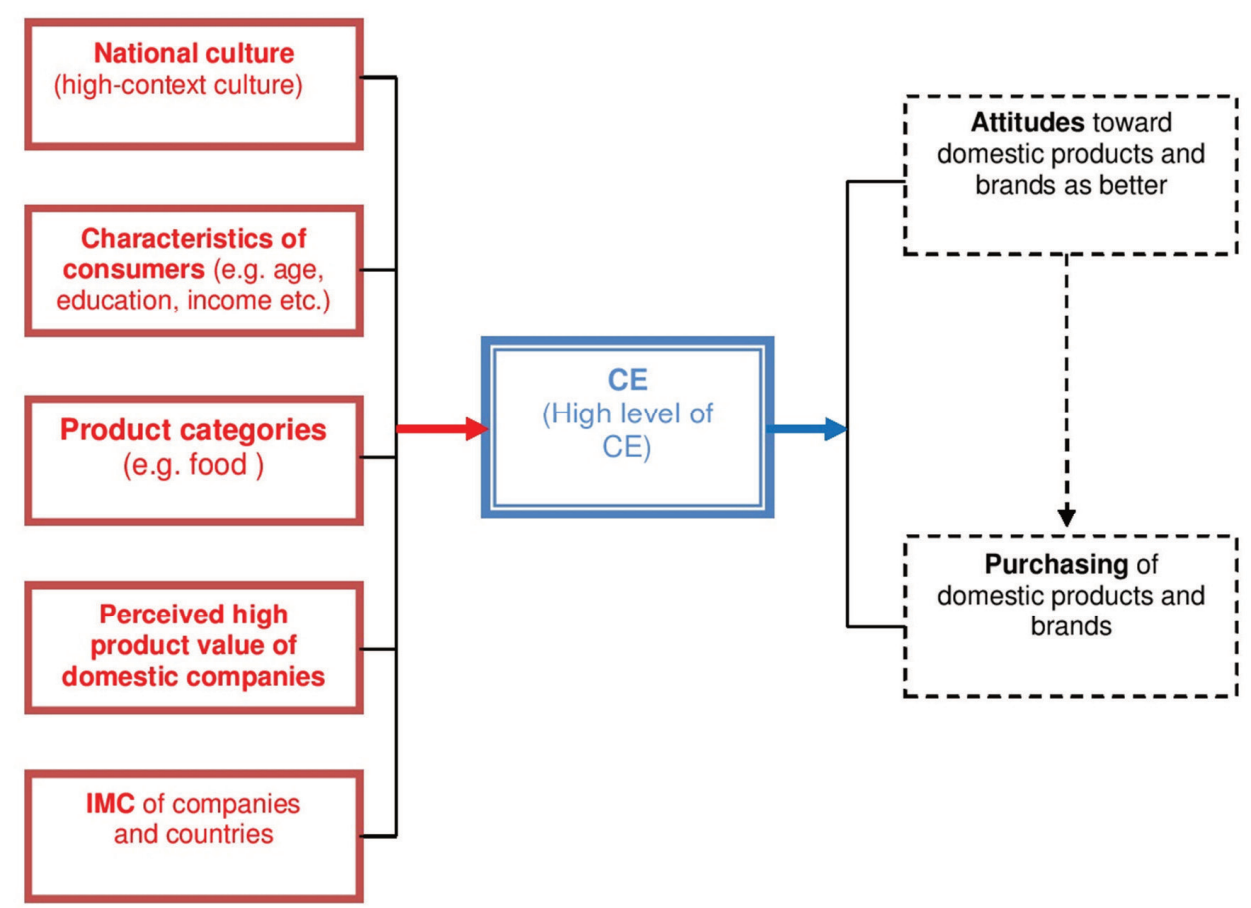

Figure 1: Antecedents and consequences of the high level of $\mathrm{CE}$ Source: Authors

Different CE in different countries also affects various marketing challenges. High CE in a certain country represents a significant marketing opportunity for domestic companies, but marketing threat for foreign companies (Figure 2).

The marketing activities that influence the creation of an opportunity for and the encouragement of CE for domestic companies are as follows:

- COO ("made in"), as the base for the positioning and differentiation strategy

- an emphasis on the importance of domestic products purchase in IMC

- engaging reference individuals and groups in encouraging the purchase of domestic products

- cooperation with the Government in order to promote the purchase of domestic products.

The activities of foreign companies aimed at decreasing the influence of CE and overcoming marketing threats are as follows:

- an emphasis on the characteristics and benefits of products as the base for the positioning and differentiation strategy

- the presentation of the characteristics and image of brands and a company ("made by the company"), instead of COO ("made in the country")

- alliances with local companies - producers and/or distributors

- a socially responsible behaviour of the company and a more widely sustainability-oriented behaviour of the company. 


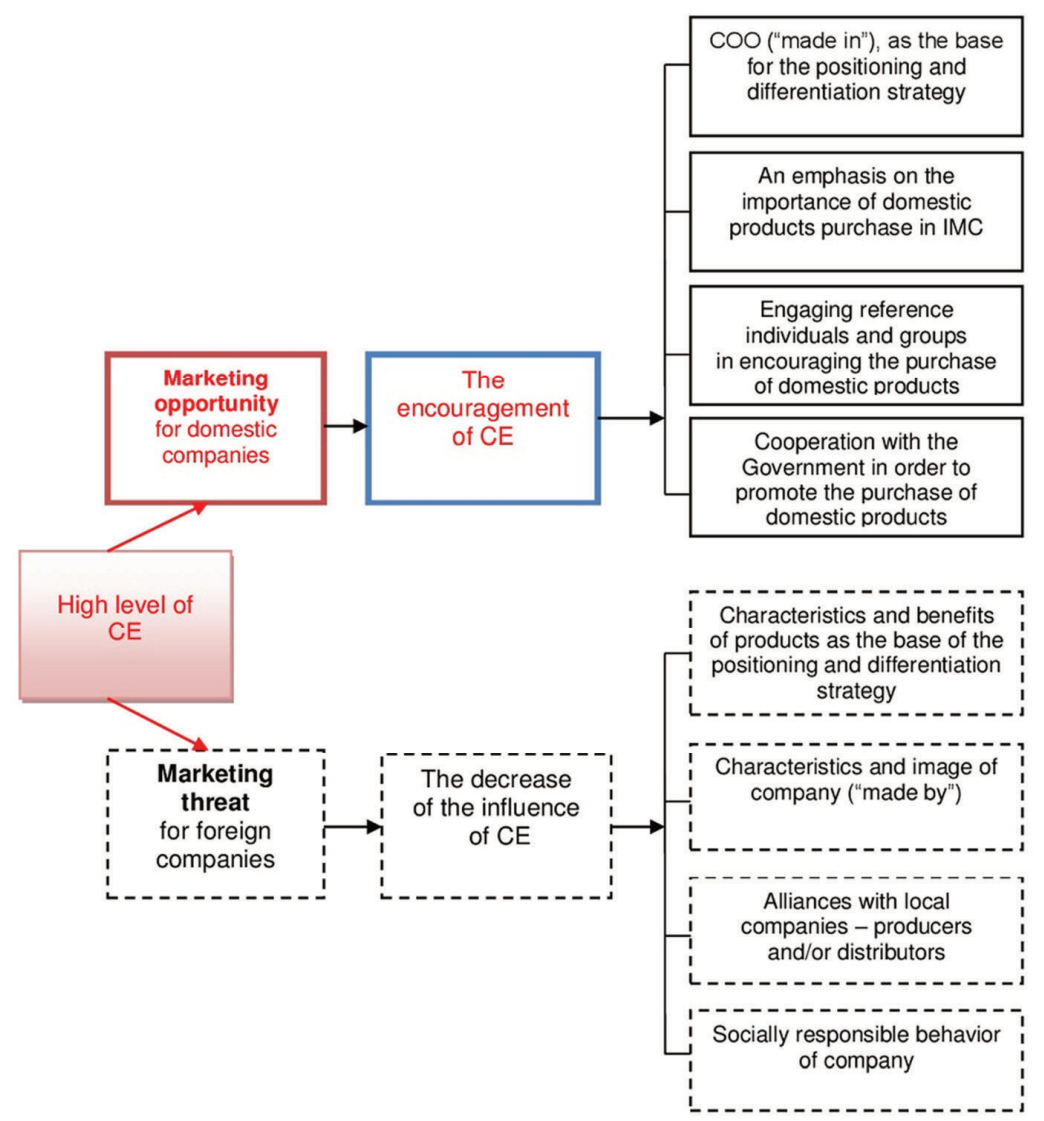

Figure 2: High level of CE and marketing challenges for companies Source: Authors

\subsection{Managerial Implications}

Our results have several important managerial implications. First, the results provide marketers with the knowledge of the market segments that are more consumer-ethnocentric. It is the base for effective target marketing (market segmentation, market targeting and market positioning). Second, this study provides marketers with useful marketing strategies and tactics for domestic and foreign companies with respect to CE.

\subsection{Limitations and Areas for Further Research}

The results of the study should be interpreted in view of a few limitations, which in turn create opportunities for future studies. The data were gathered from consumers in a particular national context: Serbia, and in town - Belgrade - as the biggest city/market in Serbia. A wider geographic reach and study in other national contexts can provide a more comprehensive understanding of CE. The relatively small sample and the sample structure could have influenced the results. It may restrict the generalization of our findings. Although CE has been the subject matter of investigation over many years, there is little research addressing companies and governments. Consumers are the most important actors for marketers and it is logical why researchers focus on consumer research. In addition to consumer research, more attention can be paid to the activities of companies and governments facing CE.

Future research should examine how companies and governments react to CE. A further study of CE would be of interest for companies and governments. Future research should concentrate on: CE in different national contexts/countries (the antecedents and the consequences of CE), CE in different product categories, the useful marketing strategies and tactics of domestic and foreign companies concerning CE in different countries, the impact of social media on $\mathrm{CE}$, the behaviour of governments in the field of $\mathrm{CE}$, etc.

A further study of the antecedents and the consequences of the high level of CE (presented in Figure 1) as the conceptual framework for ethnocentric consumer behaviour can be interesting. Future research will be needed in order to prove marketing challenges, marketing strategies and tactics for domestic and foreign companies facing $\mathrm{CE}$, which are shown in Figure 2. The results of this study can be used both for further research and in practice. 
The conceptual framework was developed so as to enable a better understanding of the behaviour of ethnocentric consumers (Figure 1). The results show the antecedents and the consequences of CE, who highly ethnocentric consumers are, the effect of ethnocentrism on consumers' buying behaviour in different product categories and how ethnocentrism can be used in the marketing of companies. The second conceptual framework was developed so as to help better understand CE, marketing challenges, strategies and tactics for domestic and foreign companies facing ethnocentric consumers. The paper presents different marketing solutions available to domestic and foreign companies (Figure 2).

In a country with a high CE, domestic companies can achieve a competitive advantage by focusing on domestic origin "roots" in the positioning and differentiation strategy. Through IMC they can additionally encourage the purchase of domestic products/services. On the other hand, foreign companies can redirect themselves towards other characteristics and benefits of products as the bases of the positioning and differentiation strategy. Furthermore, instead of pointing out the COO ("made in"), foreign companies can focus on the image of the company ("made by"). Another opportunity is an alliance with local companies - producers and/or distributors. Socially responsible behaviour of the company in a certain country can contribute to the improvement of the company's image. Information about the level of CE (as a way of consumer behaviour toward domestic companies) in a target country and/or region can help in defining the marketing strategy of companies. The marketing solutions proposed to domestic and foreign companies facing ethnocentric consumers can readily be used in practice.

\section{REFERENCES}

[1] Balabanis, G., \& Siamagka, NT. (2017). Inconsistencies in the behavioural effects of consumer ethnocentrism: The role of brand, product category and country of origin. International Marketing Review, 34(2), 166-182, DOI: 10.1108/IMR-03-2015-0057

[2] Bernabeu, R., Prieto, A., \& Diaz, M. (2013). Preference patterns for wine consumption in Spain depending on the degree of consumer ethnocentrism. , 28(1), 77-84. DOI: 10.1016/j.foodqual.2012.08.003

[3] De Nisco, A., Mainolfi, G., Marino, V., \& Napolitano, M.R. (2016). Effect of economic animosity on consumer ethnocentrism and product-country images. A binational study on the perception of Germany during the Euro crisis. European Management Journal, 34(1), 59-68. DOI:10.1016/j.emj.2015.09.003

[4] Ding, Q.S. (2017) Chinese products for Chinese people? Consumer ethnocentrism in China. International Journal of Retail \& Distribution Management, 45(5), 550-564, DOI:10.1108/IJRDM-11-2016-0212

[5] Evanschitzky, H., Wangenheim, F., Woisetschlager, D., \& Blut, M. (2008). Consumer ethnocentrism in the German market. International Marketing Review, 25(1), 7-32.

[6] Fernandez-Ferrín, P., Bande-Vilela, B., Klein, J.G., \& del Río-Araujo M.L. (2015). Consumer ethnocentrism and consumer animosity: antecedents and consequences", International Journal of Emerging Markets, 10(1), 73-88. DOI:10.1108/IJOEM-11-2011-0102

[7] Fernandez-Ferrín, P., \& Bande-Vilela, B., (2013). Regional ethnocentrism: Antecedents, consequences, and moderating effects. Food Quality and Preference, 30, 299-308. DOI:10.1016/j.foodqual.2013.06.011

[8] Filipovic, V., \& Kostic-Stankovic, M. (2011). Odnosi s javnoscu, FON, Beograd.

[9] Garmatjuk, K., \& Parts, O. (2015). Consumer Ethnocentrism in Estonian Skin Care Products Market. Procedia - Social and Behavioral Sciences, 213(1), 610-615. DOI:10.1016/j.sbspro.2015.11.458

[10] Gasevic, D., Tomasevic, D., \& Vranjes, M. (2017). Key Factors Determining the Ethnocentric Tendencies of Consumers in Serbia. Management: Journal of Sustainable Business And Management Solutions In Emerging Economies, 22(3).

[11] Haque, M.M., \& Maheshwari, N. (2015). Consumer Ethnocentrism and Influence of Role Model on Generational Cohorts' Purchase Intentions towards Herbal Products, Asia-Pacific Journal of Management Research and Innovation, 11(4) 305-312. DOI: 10.1177/2319510X15609989

[12] He, J., \& Wang, C.L. (2015). Cultural identity and consumer ethnocentrism impacts on preference and purchase of domestic versus import brands: An empirical study in China. Journal of Business Research, 68(6) 1225-1233. DOI: 10.1016/j.jbusres.2014.11.017

[13] Huddleston, P., Good, L.K., \& Stoel, L. (2001). Consumer ethnocentrism, product necessity and Polish consumers' perceptions of quality", International Journal of Retail \& Distribution Management, 29(5), 236-246. DOI:10.1108/09590550110390896

[14] Jin, Z., Lynch, R., Attia, S., Chansarkar, B., Gulsoy, T., Lapoule, P., Liu, X., Newburry, W., Nooraini, M.S., Parente, R., Purani, K., \& Ungerer, M. (2015). The relationship between consumer ethnocentrism, cosmopolitanism and product country image among younger generation consumers: The moderating role of country development status. International Business Review, Volume 24(3), 380-393. DOI: 10.1016/j.ibusrev.2014.08.010 
[15] Javalgi, R.G., Khare, V.P., Gross, A. C., \& Scherer, R.F. (2005). An application of the consumer ethnocentrism model to French consumer. International Business Review, Volume, 14(3), 325-344. DOI: 10.1016/j.ibusrev.2004.12.006

[16] Josiassen, A., Assaf, A.G., \& Karpen, I.O. (2011). Consumer ethnocentrism and willingness to buy: Analyzing the role of three demographic consumer characteristics", International Marketing Review, 28(6), 627-646. DOI: 10.1108/02651331111181448

[17] Kaynak, E., \& Kara, A. (2001). An examination of the relationship among consumer lifestyles, ethnocentrism, knowledge structures, attitudes and behavioural tendencies: a comparative study in two CIS states. International Journal of Advertising, 20(4), 455-482. DOI: 10.1080/02650487.2001.11104906

[18] Kitic, B., Kostic-Stankovic, M., Cvijovic, J., \& Cvetkovic-Lecic, D. (2015). Environmental aspect of business communications. Management: Journal for Theory and Practice Management, 20(74), 69-76. DOI: 10.7595/management.fon.2015.0004

[19] Kostic-Stankovic, M. (2011). Integrisane poslovne komunikacije, FON, Beograd.

[20] Kostic-Stankovic, M., \& Nedeljkovic, N. (2012). Stock Exchange Communication with Target Groups of Public. Management: Journal for Theory and Practice Management, 17(62), 19-27. DOI: 10.7595/management.fon.2012.0002

[21] Kragulj, D., Parezanin, M., \& Miladinovic, S. (2017). Consumer ethnocentrism in transitional economies: Evidence from Serbia. Socioloski pregled, 51(1), 59-79.

[22] Li, Y., \& He, H. (2013). Evaluation of international brand alliances: Brand order and consumer ethnocentrism. Journal of Business Research, 66, 89-97. DOI: 10.1016/j.jbusres.2011.07.027

[23] Liu, C., \& Chang, L. (2011). Keeping up with the Joneses, consumer ethnocentrism, and optimal taxation Economic Modelling, 28(4), 1519-1525. DOI: 10.1016/j.econmod.2011.02.014

[24] Liu, F., Murphy, J., Li, J., \& Liu, X. (2006). English and Chinese? The Role of Consumer Ethnocentrism and Country of Origin in Chinese Attitudes towards Store Signs. Australasian Marketing Journal (AMJ), 14(2), 5-16. DOI: 10.1016/S1441-3582(06)70057-X

[25] Marinkovic, V., Stanisic N., \& Kostic M. (2011). Consumer Ethnocentrism of Serbian Citizens. Sociologija, LIII (1), 43-58. DOI:10.2298/SOC1101043M

[26] Moon, B.J., \& Jain, S.C. (2002). Consumer processing of foreign advertisements: roles of country-oforigin perceptions, consumer ethnocentrism, and country attitude. International Business Review, 11(2), 117-138. DOI: 10.1016/S0969-5931(01)00052-X

[27] Neese, W.T., \& Hult, G.T.M. (1996). Demographic predictors of country-of-origin tendencies: a luxury sedan example. Journal of Marketing Management, 6(2), 48-60.

[28] Rakic, B., \& Rakic, M. (2017a). From Marketing Myopia to Contemporary Marketing: Transformations in Marketing in the Context of Digitalization and Sustainability (Integration of Traditional, Digital, CoCreative and Sustainability-Oriented Mindsets Inside Actors in Contemporary Marketing). E-Book Retrieved from

https://www.amazon.com/Marketing-Myopia-Contemporary-Through-Evolutionsebook/dp/B06WGV26DT/ref=sr_1_2?s=digital-text\&ie =UTF8\&qid=1487803402\&sr =12\&keywords=marketing + myopia or $\overline{\mathrm{h}} \mathrm{t}$ - $\mathrm{ps}$ ://www.books2read.com/u/bMGKkk

[29] Rakic, B., \& Rakic, M. (2017b). Sustainability-Oriented Mindset: Revolutionary Role of Sustainability Marketing as the Driver of Transformations for Sustainability. E-Book Retrieved fromhttps://www.amazon.com/dp/B071X9H1XK/ref=sr 1 1 ? s = digital-text\&ie =UTF8\&qid=1497462123\&sr=1$1 \&$ keywords $=$ Sustainability-Oriented $+\overline{\text { Mindset} \% 3 A}+$ Revolutionary + Role + of + Sustainability + Marketin $\mathrm{g}$ + as +the+Driver+of+Transformations+for+Sustainability or https://www.books2read.com/u/mvYaej

[30] Raskovic, M., Ding, Z., Skare, V., Ozretic-Dosen, Dj., Zabkar, V. (2016). Comparing consumer innovativeness and ethnocentrism of young-adult consumers. Journal of Business Research, 69(9), 36823686. DOI: 10.1016/j.jbusres.2016.03.029

[31] Seitz, C.C., \& Roosen, J. (2015). Does consumer ethnocentrism influence product knowledge? Food Quality and Preference, 43, 113-121. DOI: 10.1016/j.foodqual.2015.03.002

[32] Shankarmahesh, M. (2006). Consumer ethnocentrism: an integrative review of its antecedents and consequences. International Marketing Review, 23(2), 146-172. DOI: 10.1108/02651330610660065

[33] Sharma, S., Shimp, T. A., \& Shin, J. (1995). Consumer ethnocentrism: A test of antecedents and moderators. Journal of the Academy of Marketing Science, 23(1), 26-37.

[34] Sharma, P., \& Wu, Z. (2015). Consumer ethnocentrism vs. intercultural competence as moderators in intercultural service encounters. Journal of Services Marketing, 29(2), 93-102, DOI: 10.1108/JSM-122013-0330

[35] Shimp, T.A., \& Sharma, S. (1987). Consumer ethnocentrism: construction and validation of the CETSCALE. Journal of Marketing Research, 24, 280-289. DOI: 10.2307/3151638

[36] Sumner, W.G. (1906). Folkways: The Sociological Importance of Usages, Manners, Customs, Mores, and Morals, Ginn \& Co. New York, NY. 
[37] Supphellen, M., \& Grrnhaug, K. (2003). Building foreign brand personalities in Russia: the moderating effect of consumer ethnocentrism. International Journal of Advertising, 22(2), 203-226. DOI: 10.1080/02650487.2003.11072849

[38] Smaiziene, I., Vaitkiene, R. (2014). Consumer Ethnocentrism and Behavior in a Market of Dietary Supplements. Procedia - Social and Behavioral Sciences, 156(26), 463-467. DOI: 10.1016/j.sbspro.2014.11.222

[39] Upadhyay, Y., Singh, S.K. (2006). Preference for Domestic Goods: A Study of Consumer Ethnocentrism. Vision: The Journal of Business Perspective, 10(3), 59-68. DOI: 10.1177/097226290601000306

[40] Wang, C., \& Chen, Z. (2004). Consumer ethnocentrism and willingness to buy domestic products in a developing country setting: testing moderating effects. Journal of Consumer Marketing, 21(6), 391400. DOI: $10.1108 / 07363760410558663$

[41] Watson, J., \& Wright, K. (2000). Consumer ethnocentrism and attitudes toward domestic and foreign products. European Journal of Marketing, 34(9), 1149-1166. DOI: 10.1108/03090560010342520

[42] Zeugner-Roth, K.P., Zabkar, V., \& Diamantopoulos, A. (2015).Consumer Ethnocentrism, National Identity, and Consumer Cosmopolitanism as Drivers of Consumer Behavior: A Social Identity Theory Perspective. Journal of International Marketing, 23(2), 25-54.

Received: 2017-07-26

Revisions requested: 2018-01-12

Revised: 2018-05-17

Accepted: 2018-07-16

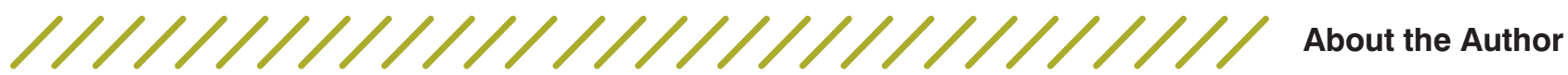

Mira Rakić

Megatrend University, Graduate School of Business Studies, Serbia rakic.mira@gmail.com

Mira Rakić is a Full Professor of Marketing, Consumer Behaviour, Digital Marketing and Strategic Marketing at Graduate School of Business. Her areas of interest include marketing, global marketing, consumer behaviour, digital economy, sustainable development and sustainability. She is the author and co-author of papers in the area of marketing, of utwo textbooks (International Marketing and Consumer Behavior), and monograph (Digital marketing). Her research profile is available at: https://www.researchgate.net/profile/Mira_Rakic

\section{Beba Rakić \\ Megatrend University, Graduate School of Business Studies, Serbia brakic@gmail.com}

Beba Rakić is a Full Professor of Marketing, International Marketing and Digital Marketing at Graduate School of Business Studies. She is the author and co-author of papers in the area of marketing, of three textbooks (Marketing, International Marketing, and Consumer Behaviour), and monograph (Digital marketing). Her main research and

publications are related to marketing, digitalization, and sustainability. Her research profile is available at: https://www.researchgate.net/profile/Beba_Rakic

\section{Ljiljana Stanojević \\ University Business Academy, Faculty of Applied Management, Economics and Finance, Serbia ljiljana.stanojevic@mef.edu.rs}

Ljiljana Stanojević is Associate Professor of Information Technology at the Faculty of

Applied Management, Economics and Finance. She is the author and co-author of papers in the area of applied information technology information systems and business intelligence, a textbook (Introduction to Geography Information Systems), a monograph

(Development of Business Intelligence Methodology). Her main research and publications are related to applied information technology and artificial neural networks for data analysis, business intelligence, and Information systems. Her research profile is

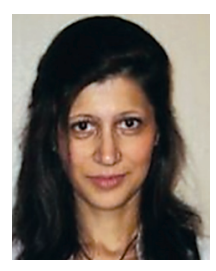
available at: https://www.researchgate.net/profile/Ljiljana_Stanojevic 